\title{
An Information-based Integration Framework to Support Building Construction Industry
}

\author{
Prince Joseph Sackey \\ Department of Information Technology, Academic City College, Accra, Ghana \\ Email: prince.sackey@accghana.com
}

Received: 02 June 2017; Accepted: 07 August 2017; Published: 08 January 2018

\begin{abstract}
Information integration provides the basis for effective team work. The research work is aimed at formulating a framework of information integration to support the building construction industry. A conceptual model was created based on the requirements obtained from the industry. Qualitative research and quantitative research were adopted for the study which involves expert opinion, data requirements and data collection method, data analysis and sensitizing concepts. Questionnaire was developed and administered based on the information obtained from the interview. Drawing on the interviews and the questionnaires administered, a framework was developed to harness the information needed for construction projects. This paper provides members such as land surveyor, contractor, quantity surveyor, engineers, architect and project manager in a team the platform to execute their work from anywhere and anytime without delay. The major advantages of this framework are: to provide members of a building construction team to work from anywhere and at any time and to articulate their activities in a way that can help develop positive work culture. Finally, the framework will enable information system developer develop a system to support building construction work activities.
\end{abstract}

Index Terms-Component, Tacit and explicit information, sensitizing concept, information integration.

\section{INTRODUCTION}

Information integration is defined as combining of all the organizations dispersed information resources in order to apply them in production, and as a means of creating new information out of different and novel combinations of existing information [1]. Information has become a globally acceptable medium for industrial development. For this reason, Information needs to be well harnessed for better usage. The presence of available information that can support a project in the building construction industry will facilitate and speed up work processes; hence is difficulty to harness this information. However, it will put impediments in the project team to complete their work as scheduled without unnecessary delays. Information, when in discrete parts, is difficult to use. It is important for companies which want to have competitive advantage to capitalize on the information gained in other projects in future projects. This ensures that mistakes are not repeated, thus giving them advantage over their competitors. Companies with the vision of remaining on top of the industry in which they operate must devote about one percent of their total revenue towards Information Management [2]. Putting together different aspects of information for the purpose of reuse to achieve a common goal is referred to as information integration.

The individual team members will be given access to all the needed information to complete a project at hand. This is because if a team leader needs information that will enable him or her execute his or her duty and the necessary information is not at hand, it will cause delay in the work processes. The problem becomes severe in situations where other members who have to deliver such information are not found on time or not available.

However, if there is a common place where all information in the organization is harness and kept at an appropriate time, this delay will be prevented because each member can log into the resource and have the necessary information needed. Many a time building construction industries may have similar projects of which they may not necessarily need to start from scratch because this project has been executed before; however, if information acquired from previous projects was not kept for reuse, the whole project will have to be started all over again leading to delays and increasing cost.

Project documentation comes with hardcopy which makes the handling of such documents difficult. This may lead to loss of documents, and destruction resulting from poor handling by team members. The research work has identified all the major activities performed at building sites and has organized them in such a way that provides access to individual members in the team who require such information to perform their tasks during and after the execution of the project.

In order to complete this research work successfully, the following objectives will be addressed:

To evaluate the building construction process activities requirements that can enable the formulation of a framework for integration of knowledge in the building construction industry.

To create a conceptual model based on the construction process activities requirement on building site.

The following are research questions the study will seek to address: 
What information is required from team members of a building construction to execute a building construction project?

How will these team members fit into a model to integrate the information from each member?

\section{RELATED WORK}

\section{A. Information Integration}

Fig. 1 is a transmission of information framework for the construction industry in Malaysia. The information transmission in this framework lay emphasis on transmission of information from the outside agencies to team member in a construction firm [3]. Its concentration was not on the information that is supposed to be shared among team members to complete a project but maintaining the Integrity of the Specifications. To make the first model in Fig. 1 properly integrate information, [3] introduced an elementary tactic of mapping transmission of information as shown in Fig. 2.

In view of these frameworks discussed, none these frameworks considered the integration of information based on disciplines and among team members within a project in the building construction industry. This paper sought to harness the knowledge based on major disciplines for building projects in the building construction industry from the design stages of the project to the completion.

\section{B. Tacit and Explicit Information}

Information which is tacit is difficult to validate and extremely personal. Understanding of individuals, guesses and perceptions is categorized under this type of information. Such information is soft and keeps in the head [4]. Tacit information is tougher to handover [1], [4] besides it forms from communal understanding [5]. An instance of tacit information is the difficulty in illustrating how to travel with an air craft prior to its use.

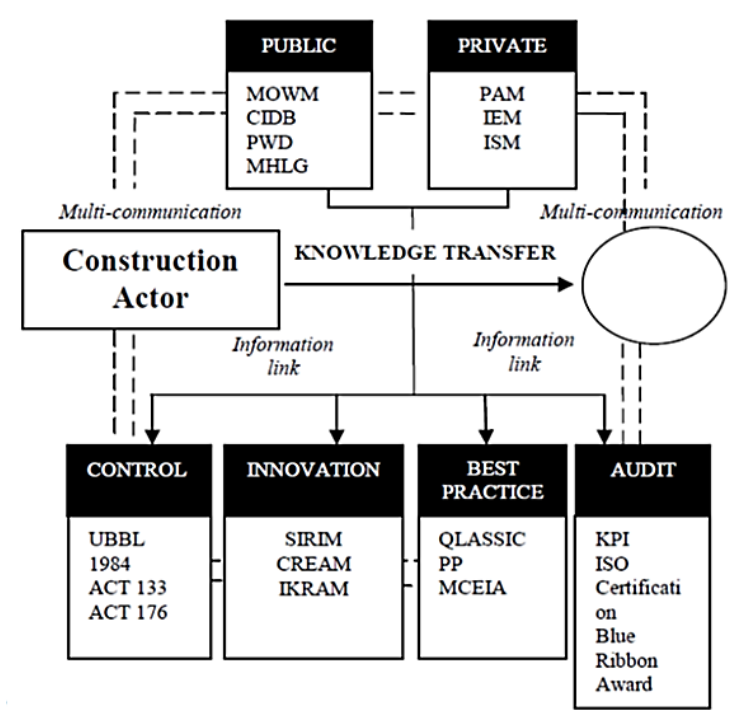

Fig.1. Transmission of Information (FK) Framework
Information which is explicit may be communicated in numbers or words. This will provide the information in codified processes and hard data form.

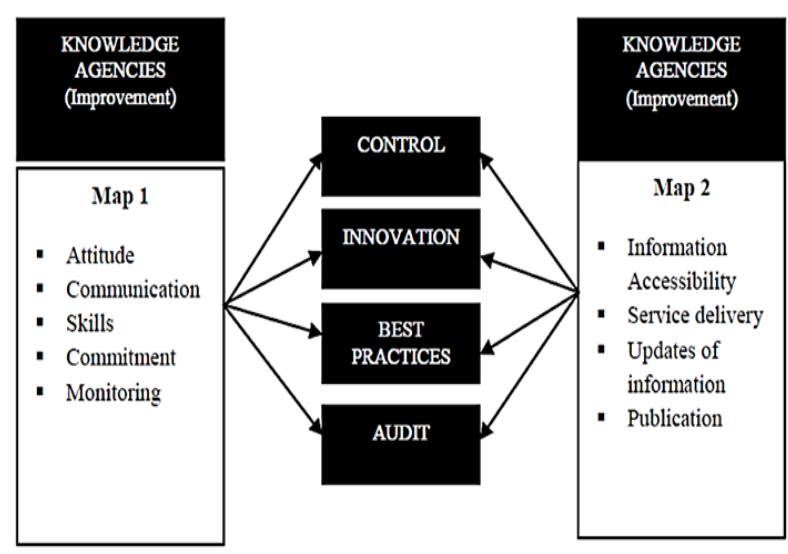

Fig.2. Information map strategy

Explicit information is independent and impersonal of the context and is also described as object and rule base [6]. Hence, explicit information can be developed by formal learning, attained without influence from the information owner, and can be deposited in one location [5]

\section{Information used in Building Construction Project}

The construction process information needs should be extracted from all stakeholders in the building industry and should be duly integrated effectively [7]. Commendable construction information integration with various phases of project development might overcome these challenges which could impede success in project execution [8].

Reference [9] inferred that there can be an important contribution from contractors when they are called to take part or share their information during the initial phase of the building construction design activities. However, as [11] suggested, lack information from contractor in terms of misinterpretation or lack of appreciation that come from construction requirements has been as a result of their absence from the initial design. Reference [12] also acknowledged that the inability of Malaysian contractors to possess enough information, which has been an obstacle for the success of construction project, is as a result from the absence of contractor involvement at the design stage of the construction processes.

In the process of building construction, it has been noted that information is a very important asset which brings the process to success [13]. It has been identified that there must be major enhancement in knowledge and information transmission within the building construction firm [14]. Nevertheless, there has been inadequate concern about transfer of information in construction processes of many countries especially Africa [15]. In view of these, this study sought to provide an efficient and effective way to disseminate information in building construction site.

D. Information Based Systems (IBS) 
Information Application System is a process that supports some individuals to utilize Information from other individuals in the sense of not really learning, or acquiring, that Information. The following are Information application technologies that back the cause and procedure: help desk systems, troubleshooting systems, decision support systems, expert systems and advisor systems [22]. It also refers as a search program which is Inference Engine (IE) and Information Base. The present Information in the Information base is deduced by the IE, which is a software program. A repository of Information in many ways can be accessed in the Information base. It was concluded that although there are many advantages of Information base system development and usage however, there is a difficulty when many individual possess the Information.

The amalgamation of Information estimation by credal sets (CSs) and Information depiction through focused acyclic graphs which brought about progress of credal networks (CNs) that is viewed generally to CSs of Bayesian networks (BNs). In view of this a formalism of CNs was used to build IBSs which in practice has shown to be effective. Based on hand-on experience, the proposed approach had satisfied many conditions which have proven to be important in effective and efficient illustration of an expert Information in a IBS. Examples are airspace surveillance and environmental monitoring. In Japan Toshiba was judged very progressive in the use of Information-based systems. They have many application types; however, the problem solving situation covers a wider range. The percentage of applications receiving operational eminence is high. The integration of technologies and techniques range by Toshiba includes fuzzy expert systems, conventional order processing systems, casebased reasoning with neural nets, simulators, etc. Toshiba is no more limited to the initial stage of their application of stand-alone systems [23].

Information-based system applications in engineering design at MIT is a computer-aided process engineering software environment that permits designers to go about steadily among various engineering tasks. The Information-based methodology for query expansion in context-aware Information outline and selection. A prototype was built to realize this model. Their experimental results confirmed that the proposed approach can improve original precision of queries. AceProject developed by Websystems International, a Canadian based company, was developed as a standalone platform to manage the organization's activities. Now it has been developed as a webbased project management suite of applications that support the framework for improved planning, irrespective of the operation's size. AceProject is designed for any person or business trying to manage projects, tasks, or just business activities in general. It provides a free entrylevel choice for organizations of small size which now can account for what happen daily, weekly, monthly or annually as recurring items and team task that the application user can request. It also provides for online project management and collaboration application [24].

\section{METHODOLOGY}

The research methodology adopted for this paper is the qualitative and quantitative research. The main goal of qualitative research is to investigate people's behavior to understand context and the particular situations they perform their actions [16]. This section uses the following subheadings to explain the chosen methodology for the research study: Expert opinion, Data Collection Method, Data Analysis and Sensitizing Concepts. The quantitative was to get the views from construction team members on how best the building construction team will fit into the model so as to integrate the information from each member.

\section{A. Expert Opinion}

Information was gathered from twelve experts. Two each of the following: project manager, quantity surveyor, structure engineer, architect, building contractor and land surveyor in three building construction companies.

\section{B. Data Collection Method}

Interviews, observations and documents were used as the data collection method. These provided an opportunity to ask questions that pertained to the research study from the experts. The field of study was observed and was related to some relevant documentation that was extracted from other researchers.

\section{Data Analysis}

Coding and Conceptualization: The main objective of coding is to move away from the experimental material in a way that will prevent it from simple duplication [17]. In the first stage of coding a large amount of data were collected and, to reduce it, key words were used to select the important ones. In the second coding, focus coding of key words were used to gather and compare data from respondents or interviewees to ascertain conclusions from the interview. Finally, theoretical coding enables the research to formulate the framework to indicate how knowledge can be integrated to support construction industry. The below table 1 shows how the detail of the description above was presented.

\section{Sensitizing Concepts}

There will be a deeper understanding of one's own empirical work when there is a discussion of existing literature throughout the process of the research work [18]. All the major team members were not involved at all stages of the construction project. These result in poor construction of project due to lack of initial knowledge contributions from contractors concerning requirement of the project and contributions from all members throughout the construction work. 
Table 1. Coding Process

\begin{tabular}{|c|c|c|c|}
\hline Raw Data & Initial coding & $\begin{array}{l}\text { Focusing } \\
\text { coding }\end{array}$ & $\begin{array}{l}\text { Theoretical } \\
\text { coding }\end{array}$ \\
\hline $\begin{array}{l}\text { What are the } \\
\text { various team } \\
\text { members in } \\
\text { the building } \\
\text { construction } \\
\text { project team? }\end{array}$ & $\begin{array}{l}\text { architect, project } \\
\text { manager, structure } \\
\text { engineer, building } \\
\text { contractor quanti- } \\
\text { ty surveyor, and } \\
\text { land surveyor }\end{array}$ & \multirow{5}{*}{$\begin{array}{l}\text { Architect- } \\
\text { Building } \\
\text { Design } \\
\text { Engineers- } \\
\text { Plumbing } \\
\text { and Electri- } \\
\text { cal Design } \\
\text { Land Sur- } \\
\text { veyor- De- } \\
\text { marcation } \\
\text { Quantity } \\
\text { Surveyor- } \\
\text { Billing and } \\
\text { Costing } \\
\text { Contractor- } \\
\text { realizing } \\
\text { project }\end{array}$} & \multirow[t]{5}{*}{$\begin{array}{l}\text { All team } \\
\text { members } \\
\text { will be part } \\
\text { of decision } \\
\text { taken from } \\
\text { initial until } \\
\text { completion. }\end{array}$} \\
\hline $\begin{array}{l}\text { What type of } \\
\text { knowledge } \\
\text { can be identi- } \\
\text { fied in each } \\
\text { discipline? }\end{array}$ & $\begin{array}{lr}\text { Design, } & \text { billing, } \\
\text { costing, realizing } \\
\text { project, demarca- } \\
\text { tion }\end{array}$ & & \\
\hline $\begin{array}{l}\text { Which of this } \\
\text { knowledge is } \\
\text { shareable and } \\
\text { not sharable? }\end{array}$ & $\begin{array}{l}\text { Design, billing, } \\
\text { costing, realizing } \\
\text { project, demarca- } \\
\text { tion, all the above } \\
\text { are sharable. }\end{array}$ & & \\
\hline $\begin{array}{l}\text { What is the } \\
\text { workflow } \\
\text { pattern among } \\
\text { team mem- } \\
\text { bers? }\end{array}$ & $\begin{array}{l}\text { Client } \\
\text { Structural Engi- } \\
\text { neer } \\
\text { Architect } \\
\text { Services Engineer } \\
\text { Client } \\
\text { Quantity Surveyor }\end{array}$ & & \\
\hline $\begin{array}{l}\text { How do the } \\
\text { team mem- } \\
\text { bers access } \\
\text { individual } \\
\text { knowledge if } \\
\text { is shareable? }\end{array}$ & $\begin{array}{ll}\text { Through } & \text { direct } \\
\text { exchange } & \end{array}$ & & \\
\hline
\end{tabular}

Fig. 3 is a sequence diagram that indicates the work process of a construction industry. The client will request to put up a building, upon which he will discuss the design with the architect. The architect will design the building with the help of the engineers (structural and services) and submit to the quantity surveyor to estimate the total cost of the building. The architect will submit the cost to the client, upon acceptance; he will award the contract to the contractor. As the building is under construction the architect, engineers and the quantity surveyor will provide support services to the contractor until the completion of the building.

Fig 4 is the proposed sequence diagram. The land surveyor will submit the site plan to the framework, which the architect will access and discuss with the project manager as to how the client wants the building to be. Based on the discussions, the architect will draw the ini- tial design and submit the initial design into the framework.

The framework will compare the initial design with the land size to see whether the proposed structure is feasible. The quantity surveyor will use the initial design to provide advice on land economic matters.

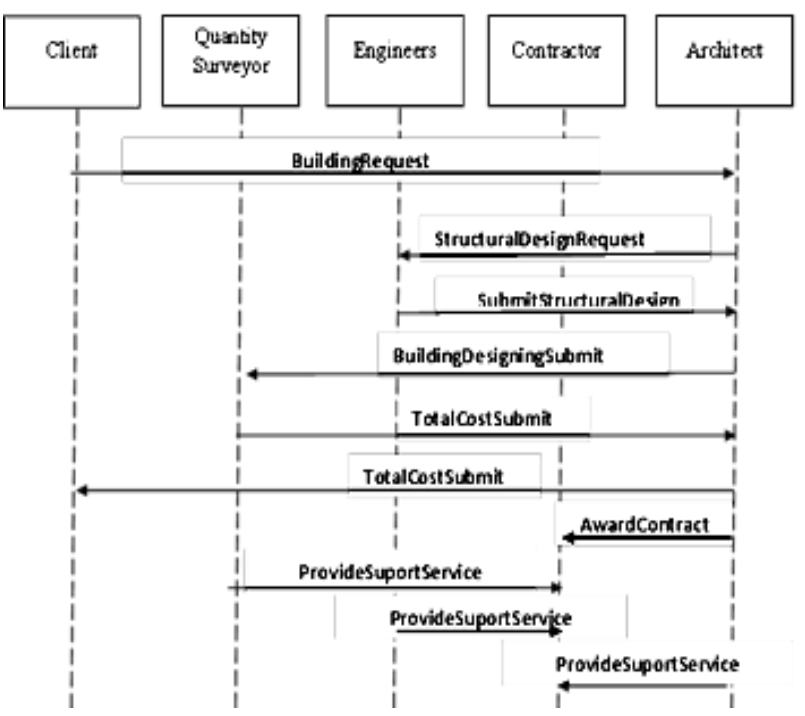

Fig.3. Sequence Diagram for Current Work Process in Construction Industry

The engineers will also provide their designs based on the initial design. The contractor will also contribute by giving advice as to the building requirements needed in the initial stage of the design development of the building. This will enable the contractor to have full knowledge of the building.

The architect will access all these contributions to assist him/her to provide the final building design. The quantity surveyor will access the final building design to estimate the total cost of the building and submit to the framework. The contractor will be awarded the contract through the framework and the contractor will acknowledge acceptance through the framework. During the construction of the building, the architect, engineers and the quantity surveyor will provide support service to the contractor until the completion of the building. Modification or upgrade can be done simply through the framework and each team member can easily access it immediately. Documents and advice kept in the framework can be reuse when the need arises. 


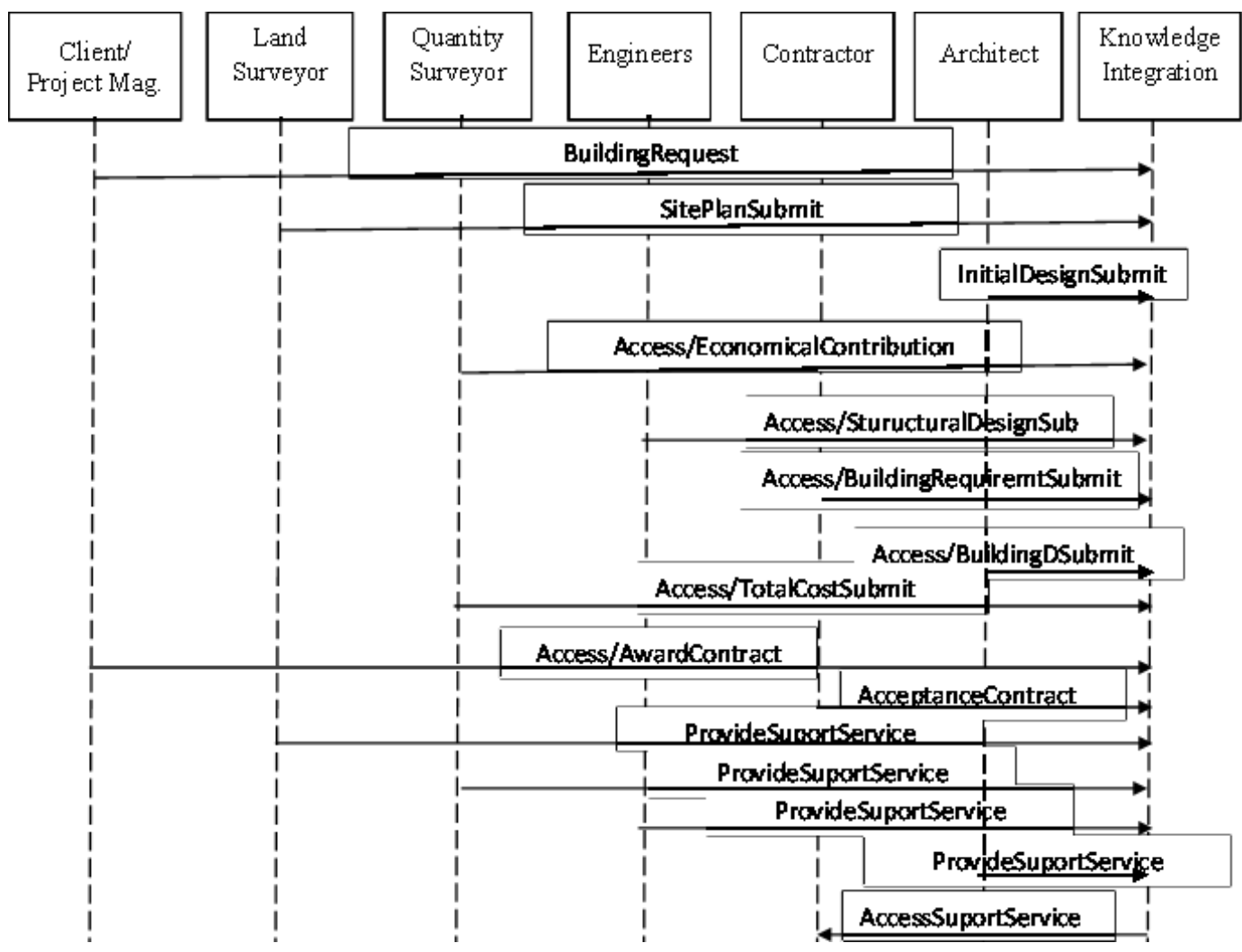

Fig.4. Sequence Diagram of Information integration for Construction Industry

\section{RESULTS}

Fig. 5 is an Information-Based Framework to support building construction industry. The framework was formulated based on the major disciplines for building construction projects. The major disciplines that were taken into consideration are land surveyor, architect, engineers, quantity surveyor, contractor and the project manager.

The framework addresses the gap identified from the literature document and interviews with expert. The workflow in the construction project, as shown by literature and the interviews, starts from the client having the idea to build and discussing with architect. Then the architect collaborates with the engineers to produce the drawings. The drawings are handed over to the quantity surveyor for bill of quantity and estimation of project cost. The next stage is to award the project to the contractor. In this sense, the contractor does not contribute during the initial design stage of the building project which results in poor construction work. Reference [19] confirms the fact that there can be an important contribution from contractors to share their information during the initial phase of the building construction design activities. If not, it will result in misinterpretation or deficiency in the requirements from contractors. The inadequacy of contractors' information regarding a project is the outcome of their absence during initial design stage of the project [20]. The emphasis made by [21] concerning information integration of construction project at each phase of the pro- ject development may curb the challenges with respect to quality, cost and time during project implementation.

In order to present good and economic building design, all the team members, land surveyor, architect, engineers, quantity surveyor and contractor should be present at the site for their initial contribution of information. The architect with the help of the engineers will put all these experts' initial information contribution about the project into consideration to design the building. The designed work will be given to the quantity surveyor to estimate quantity of material and total cost of the building, which will lead to the bill of quantity. He will properly execute this through the contributions from all the team members at this stage. This outcome will be communicated to the project manager who is the representative of the client to inform the client about the total cost of the construction project to be discussed with the team. Acceptance or rejection may be considered from the client base on the funds available for the project.

From the workflow discussed at each stage of the process, information will be available to all the team members. If the total cost of the construction is accepted by the client, then the contract will be awarded the contractor to begin construction. Because, the contractor was involved during the initial stage of the design work, it will be easy to understand the design. Again, there will be contributions from all the team members from the initial stage of construction to completion through the framework. This will be easily facilitated through the implementation of the framework. 


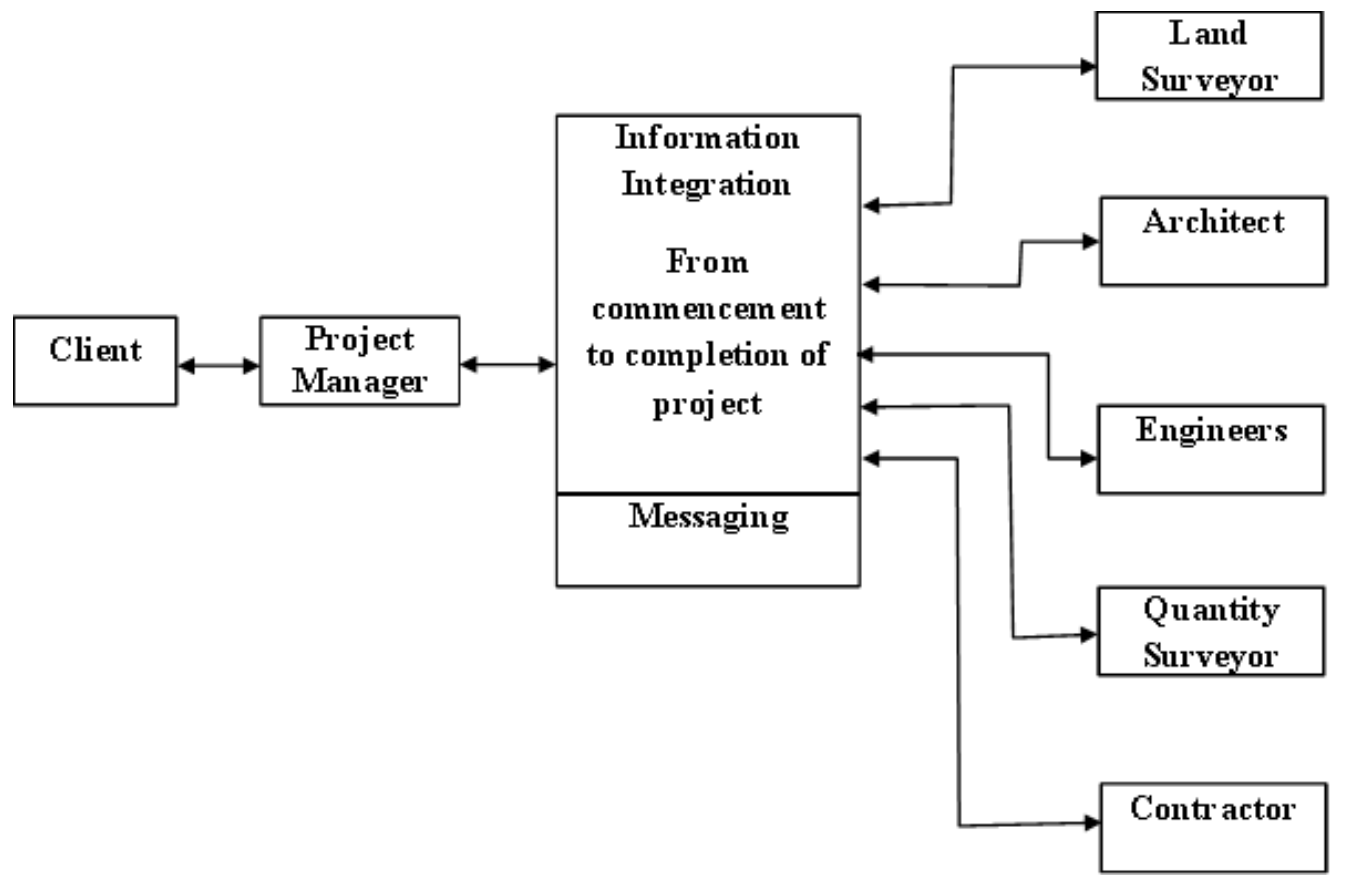

Fig.5. A Knowledge-Based Framework to Support Building Construction Industry

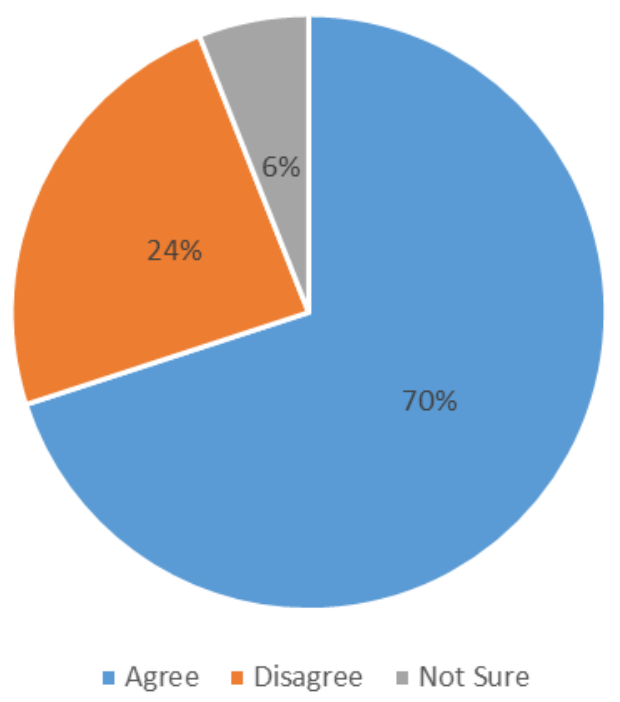

Fig. 6 Building Construction information is Explicit

Fig. 6 indicates that 35 respondents representing $70 \%$ agreed that information used for building construction projects are explicit. This provide the basis that information for building construction is sharable. $12(24 \%)$ respondents also disagreed and $3(6 \%)$ were not sure on the issue.

Fig. 7 provides responses from respondents, $5(10 \%)$ accept that the major information used for building construction projects are in the form of text based documents, $6(12 \%)$ accepted drawings to be the major document, however, 39 respondents which represents $78 \%$ are of the view that both text and drawing are the major forms of information for building construction projects.
It is recorded in Fig. 8 that 35 respondents representing $70 \%$ accepted that building construction team members need to work at different times. For this reason, it has been necessary for the use of the model to serve as a platform for the various contribution from the individual team members. In addition, $10(20 \%)$ are of view that their work should be at the same time and $5(10 \%)$ also accepted both, that is different times and same time should be used.

From the Table 2 the probability value is greater than the significance level, so the hypothesis that harnessing all information needed for a building construction on one platform will help is accepted. This will enable all documents needed for building construction project to be put on a system that will enable all the members in the construction team to access and make necessary changes and contributions to the whole team members.

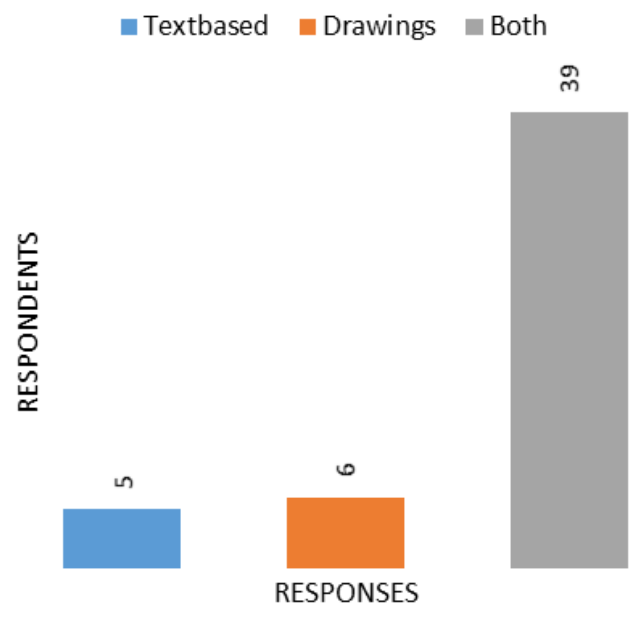

Fig.7. Forms of Information 


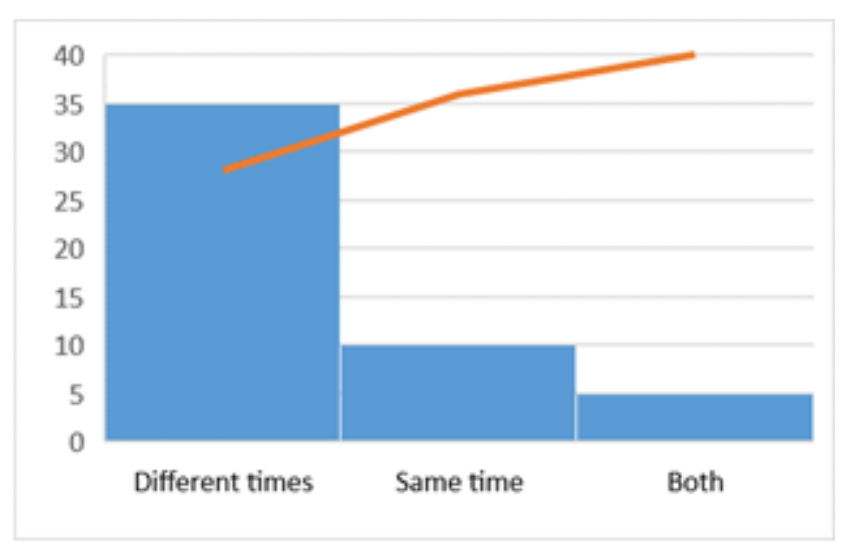

Fig.8. Team member Times of Work

Table 2. Harnessing all information needed for a building construction on one platform will help

\begin{tabular}{|l|l|l|l|l|l|}
\hline & $\begin{array}{l}\text { Sum of } \\
\text { Squares }\end{array}$ & & $\begin{array}{l}\text { Mean } \\
\text { Square }\end{array}$ & F & Sig. \\
\hline $\begin{array}{l}\text { Between } \\
\text { Groups }\end{array}$ & .889 & 1 & .889 & 11.815 & .001 \\
\hline Within Groups & 3.611 & 48 & .075 & & \\
\hline Total & 4.500 & 49 & & & \\
\hline
\end{tabular}

\section{CONCLUSION}

This paper specifically provided building industries with an information-based integration framework to facilitate construction projects. All team members can contribute to this information-based framework from the initial stage of construction to its completion. It will further harness the individual information that can be accessed by each member if the need arises. It will again keep all contributed information in the framework for future use. Projects need not be always started from the scratch since related information needed is kept.

The study will further look at integration of software to provide a platform that members of the building construction industry will used within the same environment to execute their task. Based on the information-based integration framework a system will be built to integrate knowledge to support construction industry.

\section{ACKNOWLEDGMENT}

Is our desire to express our sincere appreciation to $\mathrm{Mr}$. Ansong Danso for his contribution that brought the work to successfully completion.

\section{REFERENCES}

[1] Grant, R. M, "Toward a Knowledge-Based Theory of the Firm." Strategic Management Journal 17(Winter Special Issue):, 1996, pp.109-122.

[2] Bullen, D, Corporate Training \& Development: How Top Companies Make The ROI Case For Employee Training. NY: Apollo light speed, 2014. Accessed from https://mitpress.mit.edu/sites/ default/.../9780262015080_ sch_0001.pdf on 4/11/2015

[3] Moh'd A. Z and Hilary, D, Knowledge transfer: A model framework for construction knowledge integration. Con- ference Papers. Paper 20. Geelong: Bond University ePublications@bond, 2011, Access from http://epublications.bond.edu.au/cgi/viewcontent. cgi?article $=1019 \&$ context $=$ aubea_2011 on 23/10/2016

[4] Ruppel, C., Harrington, S, Sharing Knowledge Through Intranets: A Study of Organisational Culture and Intranet Implementation. IEEE Transactions on Professional Communication, 2001, vol. 44, issue 1, pp.37-52.

[5] Lam, A, Tacit Knowledge, Organisational Learning and Societal Institutions: An Integrated framework. Organisation Studies (Walter de Gruyter GmbH \& Co. KG.) 2000, vol. 21, issue 3, pp.487-513.

[6] Jonsson, A, Kuskapsöverföring och knowledge management. Malmö: uppl. red. Liber AB, 2012.

[7] Eliufoo, H. K. (2005). Knowledge creation and transfer in construction organisations, PhD Thesis, Tanzania: Royal Institute of Technology.

[8] Anderson, S.D. Fisher, D.J. and Rahman, S.P, Integrating constructability into project development: a process approach, Journal of Construction Engineering and Management, 2000, 126 (2), pp 81-88.

[9] M. Young, The Technical Writer's Handbook. Mill Valley, CA: University Science, 1989.

[10] Alshawi, M. and Underwood, J, Improving the constructability of design solutions through an integrated system, Journal of Engineering, Construction and Architectural Management, 1996, 3(1/2), pp. 47-67.

[11] Arditi, D., Elhassan, A. and Toklu, Y.C, Constructability analysis in the design firm, Journal of Construction, Engineering and Management, 2002, 128(2), pp 117-126.

[12] Saghatforoush, E., Hashim, S., Jaafar, M. D. and AbdulKadir, M.R, Constructability implementation among Malaysian Building Contractors, Scientific Research, 2009, 29(4), pp 518-532. Science, Department of Energy. Accessed from http://www.au.af.mil/au/awc/awcgate/doe /benchmark/ch05. pdf on 09/12/2015.

[13] Chen, L., and Mohamed, S. (2008), Impact of the internal business environment of knowledge management within construction organisations. Construction Innovation, vol.8(1), pp 61-81.

[14] Zaidi, M.A. and Davies, H, A question of continuing control - balancing building quality of housing and building codes, In Proceedings, Building Australia's Future International Conference, September pp. 20-23, 2009, Gold Coast, Australia.

[15] de Silva, N., Dulaimi, M., Ling, F. and Ofori, G, Improving the maintainability of buildings in Singapore, Building and Environment, 2004, vol. 39(10), pp 1243-1251.

[16] Mishler, E. G, Validation in inquiry-guided research: The role of exemplars in narrative studies. Harvard Educational Review, 1990, 60, 415-441.

[17] Kuckartz, U, Einführung in die computer gestützte Analyse qualitativer Daten. 3rd edition. Wiesbaden: VS Verlag für Sozialwissenschaften, 2010.

[18] Corbin, J., \& Strauss, A, The basics of qualitative research (3rd ed.) Los Angeles, CA: Sage, 2008.

[19] Alshawi, M. and Underwood, J, Improving the constructability of design solutions through an integrated system, Journal of Engineering, Construction and Architectural Management, 1996, 3(1/2), pp 47-67.

[20] Arditi, D., Elhassan, A. and Toklu, Y.C, Constructability analysis in the design firm, Journal of Construction, Engineering and Management, 2002, 128(2), pp 117-126.

[21] Anderson, S.D. Fisher, D.J. and Rahman, S.P, Integrating constructability into project development: a process approach, Journal of Construction Engineering and Management, 2000, 126 (2), pp 81-88. 
[22] Becerra-Fernandez, I. and Sabherwal, R. (2010). Knowledge Management: Systems and Processes. Armonk (N.Y.); London: M.E. Sharpe.

[23] Edward, F., Peter E. F., Bruce B. J., Penny N. H, Herbert S., Howard S., Robert S. E (1993) Knowledge-Based Systems In Japan. Japanese Technology Evaluation Center Japan: WTEC Hyper-Librarian

[24] Heather, C. (2012). Cloud-based project app now supports repetitive tasks. ZDNet. Accessed from http://www.zdnet.com/article/cloud-based-project-appnow-supports-repetitive-tasks/ on 11/10/2016

\section{Authors' Profiles}

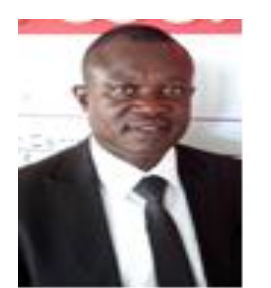

Prince J. Sackey comes from Accra, James-Town, Ghana. He holds B.Ed Vocational and Technical, M.Ed Information Technology and M.Sc Information Technology from University of Education Winneba, Kumasi-Ghana, University of Cape Coast, Cape Coast-Ghana, and Kwame Nkrumah University of Science and Technology, Kumasi-Ghana respectfully. He obtained B.Ed in 2003, M.Ed in 2012 and MSc in 2017.

How to cite this paper: Prince Joseph Sackey," An Information-based Integration Framework to Support Building Construction Industry", International Journal of Information Engineering and Electronic Business(IJIEEB), Vol.10, No.1, pp. 31-38, 2018. DOI: 10.5815/ijieeb.2018.01.05 